\author{
Петро Михайлович Малежик ${ }^{1}$, Галина Володимирівна Ткачук ${ }^{2}$ \\ ${ }^{1}$ кандидат фізико-математичних наук, докторант \\ Національний педагогічний університет імені М.П. Драгоманова \\ ORCID ID 0000-0001-6816-988X \\ p.m.malezhyk@npu.edu.ua \\ ${ }^{2}$ доктор педагогічних наук, доцент \\ Уманський державний педагогічний університет імені Павла Тичини \\ ORCID ID 0000-0002-6926-1589 \\ galanet82@gmail.com
}

\title{
ОРГАНІЗАЦІЯ ПРАКТИКО-ТЕХНІЧНОЇ ПІДГОТОВКИ МАЙБУТНІХ ІТ-ФАХІВЦІВ ЗА ДОПОМОГОЮ ВЕБІНАРІВ
}

Анотація. Аналіз сучасної наукової та навчально-методичної літератури дозволив дійти висновку, що сьогодні $є$ недостатньою кількість професійно-орієнтованої навчальної літератури 3 використання технології вебінару в навчальному процесі. В даній статті подано комплексне дослідження, в якому вивчаються питання програмного забезпечення, організаційно-методичних вимог до проведення вебінарів, вибір платформи. Розглянуто передумови, описано процес створення, проаналізовано функціональні характеристики та результати функціонування системи навчання технічних дисциплін майбутніх фахівців 3 інформаційних технологій. Серед значної кількості відомих платформ для підтримки проведення вебінарів виокремлено платформу BigBlueButton, яка $\epsilon$ безкоштовним і вільно поширюваним програмним забезпеченням з відкритим вихідним кодом. Описано та рекомендовано низку організаційно-методичних заходів для проведення успішного вебінару. Відзначено, що дотримання методичної, технічної та організаційної складових проведення вебінарів $є$ надзвичайно важливим для досягнення позитивного результату у підготовці фахівців. Показано, що використання технології вебінарів значно розширює можливості організації освітнього процесу, сприяє формуванню у майбутніх IT-фахівців системи технічних понять, знань та умінь в галузі проведення онлайнових занять $\mathrm{i}$, таким чином, надає можливість удосконалити практикотехнічну підготовку студентів. Попри всі незручності, практично всі види аудиторних занять у традиційній освіті можуть бути реалізовані засобами вебінарів. Проте, ряд проблем такої технології як форми організації навчання не дають підстави для повної заміни традиційного аудиторного навчання. Її використання уможливлює значно покращити та вдосконалити освітній процес, перевести на інший рівень процес осмислення навчального матеріалу, урізноманітнити форми організації навчальної діяльності.

Ключові слова: майбутні ІT-фахівці, освітній процес, технічні дисципліни, практико-технічна підготовка, організація вебінарів.

Постановка проблеми. Стрімке проникнення інформаційних технологій в усі галузі виробничої діяльності, політики, освіти і науки є характерною ознакою світового співтовариства, що вступило в інформаційну стадію свого розвитку. В зв'язку з цим інформатизація освіти набуває значення одного 3 пріоритетних напрямів розвитку майже всіх закладів вищої освіти (3ВО). Розвиток і постійне вдосконалення засобів ІКТ зумовлюють внесення постійних змін в інформаційно-освітнє середовище ЗВО, серед яких важливого значення набувають зміни, що стосуються форм організації освітнього процесу. В прогностичних визначеннях нових способів отримання освіти та підвищення кваліфікації в Європі, зроблених Свропейською комісією на 2020-2030 pp. [2], міститься низка відповідних висновків. Виокремимо найважливіші з них:

- засоби Інтернет і мобільні Інтернет-пристрої стануть традиційною формою отримання освіти та основним інструментом для навчання;

- використання багатокористувацьких віртуальних навчальних середовищ стане необов'язковим відвідування аудиторій університетів;

- системи та послуги будуть розроблятися з метою забезпечення групового взаємного навчання серед зацікавлених учнів та студентів;

- мультимедійні матеріали, розміщені в Інтернеті, будуть визнаватися як «законні» публікації для вчених.

Отже, навчання, що грунтується на використанні Інтернет-технологій для створення, управління, добору освітнього контенту, зберігання відомостей про студентів та для контролю їх успішності, для спілкування та комунікацій стає традиційною основою освітнього процесу. 
Нині низка методичних проблем впровадження дистанційних технологій навчання може розв'язуватись через застосування технології онлайнових семінарів, які більше відомі під назвою вебінар.

«Вебінар - це технологія, використання якої дозволяє в повній мірі відтворити умови спільної роботи організації навчання, а саме семінарського, лабораторного занять, лекцій, використовуючи засоби аудіо-, відео- обміну даними та спільної роботи з різноманітними об’єктами» [1]. Тобто вебінар $\epsilon$ новою формою організації освітнього процесу і своєрідним онлайн-аналогом традиційної форми навчання - лекції або семінару, в межах яких можна організувати подання навчального матеріалу, обговорення та закріплення.

Відповідно до визначення, наведеного в Кембриджському словнику [8], термін «webinar» $\mathrm{\epsilon}$ скороченням від «web-based seminar», під яким розуміють онлайновий семінар, що проводиться за допомогою веб-технологій у режимі реального часу, тобто синхронно для всіх учасників. Однак термін вебінар слід трактувати більш широко, вказуючи на те, що це освітня інформаційнокомунікаційна технологія, організована в мережі Інтернет за допомогою спеціального програмного забезпечення, через яке здійснюється очне передавання навчальних матеріалів й контроль знань, переважно в динамічному режимі.

Безперечно, цей вид занять $є$ перспективним і ефективним, проте нині його використання в освіті ще не набуло належного поширення. Вважаємо, що питання використання вебінарів у педагогічній практиці, з одного боку, є актуальним, з іншого боку - проблемним, оскільки лише невелика частка освітян використовує вебінари для організації навчання, тоді як більшість 3 них послуговуються традиційними технологіями.

Аналіз останніх досліджень. Проведений аналіз наукових праць засвідчує, що вітчизняні вчені вивчають проблему впровадження вебінарів у освітній процес (Н. В. Морзе, О.В.Ггнатенко, Л. В. Калачова, В. М. Кухаренко, І.В.Брунець, С. Г. Литвинова, Л. Г. Клейно, В.О.Гринько, В. О. Царенко). Різні аспекти використання середовищ проведення вебінарів висвітлено в дослідженнях закордонних авторів (Д. Кеган (D. Keegan), Є. Швенке (E. Schwenke), Х. Фрітч (H. Fritsch), Ф. Мартін (F. Martin) та ін.).

На основі аналізу отриманих результатів значної кількості досліджень зазначимо, що у роботах вище названих науковців проаналізовано актуальні питання, які стосуються окремих аспектів застосування вебінарів у процесі підготовки фахівців різних профілів, тоді як комплексне дослідження, що стосується організації практико-технічної підготовки майбутніх IT-фахівців за допомогою вебінарів, наразі немає.

Метою написання статті є обгрунтування доцільності використання вебінарів у процесі практично-технічної підготовки майбутніх фахівців з інформаційних технологій.

Подання основного матеріалу. Проведення вебінару, як правило здійснюється через сервіси в мережі Інтернет, через які надаються відповідні послуги, що можуть бути як безкоштовними, так i платними. Для цього необхідно зареєструватися на відповідному сайті та ввійти у віртуальний клас. Використання безкоштовного сервісу передбачає участь у вебінарі не більше 25 осіб.

Технологія організації вебінарів як форма організації навчання стала поширеною через низку переваг. Виокремимо найголовніші з них $[3,4]$ :

- відсутність плати за оренду залу, обладнання, друковані матеріали, транспортні витрати. Для проведення конференцій, семінарів, круглих столів це є важливим і актуальним. Єдиною витратою для такого заходу може бути оплата за надання доступу до мережі Інтернет;

- можливість організувати навчання на відстані, що не передбачає приїзд чи прихід учасників на захід. Слухати лектора можна перебуваючи вдома або на роботі;

- масовість навчання, оскільки використання деяких платформ надає змогу проводити семінар для великої кількості учасників із різних куточків країни та світу;

- зворотній зв'язок, оскільки всі учасники мають змогу спілкуватись із ведучим та іншими слухачами через засоби чату (найчастіше) або за допомогою відеозв'язку, коли адміністратор перемикає ролі і перетворює слухача у ведучого і навпаки;

- можливість у процесі проведення вебінару доповідачеві надати, а слухачам перейти за посиланням на відповідний ресурс в мережі;

- вебінар можна записати та зберегти у відповідному відеоформаті і розмістити на будь-якому pесурсі, наприклад у системі дистанційного навчання (СДН), на сайті, у блозі, або зберегти на традиційному носієві і надавати за вимогою. Серія вебінарів відповідної тематики або напряму дає змогу створити електронний навчальний відеокурс.

Ефективність і зручність використання вебінарів є сильними сторонами цієї технології, проте існують і слабкі сторони ії впровадження. Зокрема, вказують на такі недоліки цієї технології [4]: 
- Штучність та віртуальність участі. Факт аудиторної участі слухачів важливий у процесі обговорення, оскільки доповідачеві важливо бачити емоції слухачів і відповідно реагувати на них для підтримання уваги. Крім того, в деяких людей виникають складності сприйняття матеріалу на слух або з екрану монітора і їм важливо фізична присутність;

- Організація практичних занять. Таке заняття важко провести, оскільки ведучий не може прослідкувати, на якому етапі виконання завдань знаходиться той чи інший учасник, які труднощі виникають під час виконання; слухачам іноді важко пояснити, що в них виходить не так. Тому зазвичай вебінари використовуються для проведення семінарів, де переважає обговорення, бесіда, розповідь;

- Складність реалізації виховного складника заняття. Така потреба з'являється у випадку підвищення мотивації до навчання конкретного студента, коли необхідно працювати з врахуванням його особистих якостей, надавати індивідуальну консультацію. У межах проведення вебінару це здійснити важко, а іноді зовсім неможливо;

- Технічне забезпечення. Для повноцінної участі у вебінарі слухачам потрібно мати такі технічні засоби, як навушники, мікрофон, під’єднання до мережі Інтернет. У процесі двостороннього відеообговорення до таких засобів також додається відеокамера.

Очевидно, що ці обмеження не є значною перешкодою на шляху до використання вебінарів. Наприклад, виховна робота з учасниками може бути проведена напередодні організації вебінару, а практичне заняття, хоч і складно, все ж таки можна провести, якщо правильно його продумати, передбачити всі можливі помилки під час виконання практичних завдань.

Професійна підготовка майбутніх IT-фахівців на факультеті інформатики Національного педагогічного університету імені М. П. Драгоманова здійснюється у галузях знань 12 «Інформаційні технології» (спеціальності 121 «Інженерія програмного забезпечення», 122 «Комп’ютерні науки», 126 «Інформаційні системи і технології»), де вагому частину в навчальних планах складають дисципліни технічного спрямування такі як: «Теорія електричних та магнітних кіл», «Архітектура комп’ютера», «Операційні системи», «Комп'ютерні системи». Навчання кожної 3 цих дисциплін складається 3 лекційних та лабораторних занять. Вивчення даних дисциплін переважно здійснюється в аудиторії, із залученням реальних обчислювальних пристроїв, 3 використанням реального обладнання, проте змістову частину практико-технічної підготовки в межах цих дисциплін можна розкрити в межах вебінарів.

У своїй майбутній діяльності такі фахівці будуть використовувати моделі та методи, реалізація яких потребує відповідних ресурсів сучасних ІКТ. Застосування вебінару, як форми проведення практико-семінарських занять в такому випадку має подвійне значення (рис.1): як одна із складових методичної системи навчання та змістове - як опанування однією із інформаційних технологій майбутніми IT-фахівцями.

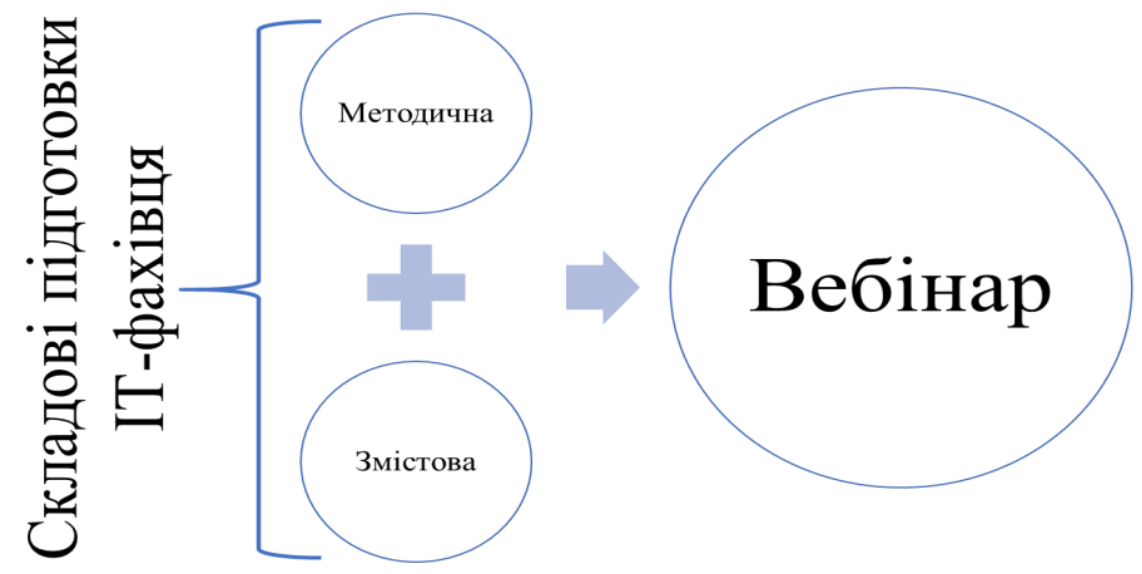

Рис.1. Методична та змістова складові підготовки ІT-фахівия у процесі використання вебінарів.

Для організації навчальної діяльності між географічно віддаленими користувачами в режимі реального часу 3 використанням вебінару, необхідне відповідне програмне забезпечення. Така діяльність може бути організована як у веб-просторі мережі Інтернет, так і в локальній мережі. Враховуючи наведений в літературних джерелах наявний досвід використання, а також власний, можна вказати на кілька платформ щодо надання набору необхідних інструментів та функцій для реалізації інтерактиву (живої взаємодії зі слухачами та максимального залучення студентів до навчання), і які є найбільш прийнятними для використання у процесі навчання технічних дисциплін майбутніх фахівців з інформаційних технологій. 
1. GoToWebinar. Компанія пропонує на період тріального використання програми не тільки кімнату на 15 користувачів, але й повноцінну цілодобову технічну підтримку. Забезпечується під'єднання до вебінару з Mac, PC, iPad ${ }^{\circledR}, \mathrm{iPhone}{ }^{\circledR}$ або Android пристроїв. Пакет Professional на 150 учасників за 12\$/ місяць. Bussiness на 250 учасників за $15 \$$ / місяць. Enterprise до 3000 учасників [7].

2. Webex. В даному середовищі окрім стандартних функцій є можливість мобільного доступу (навіть 3 iPhone або IPad). Тарифний план починається с 19\$ місячної підписки за кімнату с 8 користувачами. Тріальна пропозиція: 14-денна безкоштовна пробна версія для 25 учасників [9].

3. Webinar.ua. В разі використання даної платформи для проведення вебінарів забезпечується під’єднання з PC, iPad® ${ }^{\circledR}$, iPhone ${ }^{\circledR}$ або Android пристроїв. Кількість під’єднань можлива від 3 до $1000[10]$.

4. Etutorium. Дана платформа позиціонується як освітня, в ній міститься найбільший набір необхідних інструментів та функцій для реалізації інтерактивної взаємодії. Термін від 14 днів дає змогу працювати у безкоштовному тестовому доступі до всіх функцій [6].

5. BigBlueButton. Це рішення з повністю відкритим кодом для користувачів платформи Linux. Для роботи на Windows необхідно встановити додаткову віртуальну платформу (все це детально розписано на сайті розробників) [5].

У процесі вибору програмного забезпечення для організації вебінарів основною характеристикою в більшості випадків є простота і зручність його використання, а також вартість. Серед значної кількості відомих платформ для підтримки проведення вебінарів проаналізуємо платформу BigBlueButton, яка $\epsilon$ безкоштовним і вільно поширюваним програмним забезпеченням 3 відкритим вихідним кодом. BigBlueButton $€$ кросплатформною системою та належить до програмних продуктів, що розгортаються на апаратних засобах відповідної організації (сервері ЗВО, орендованому сервері провайдера, на сервері в мережі Інтернет).

Вибір платформи BigBlueButton обумовлений ще й тим, що ії легко можна інтегрувати в систему дистанційного навчання (наприклад, Moodle) або освітній сайт. У СДН вебінар можна додавати до будь-якого електронного навчального курсу (ЕНК) у вигляді окремого модуля, а на сайті - в будьякій частині сторінки у вигляді окремого блоку. Платформу BigBlueButton можуть використовувати також некваліфіковані користувачі, оскільки в ній передбачено невелику кількість функціональних, простих у використанні засобів. Функціонально за допомогою системи BigBlueButton можна забезпечити такі види діяльності:

- проведення звукової та/або відеоконференції;

- демонстрація презентацій (у форматі *.pdf);

- запис відеоконференції (у форматі *.flv);

- демонстрація екрана доповідача (робочого столу, вікна програми тощо);

- обмін файлами між користувачами;

- управління відеоконференцією (призначення доповідача, дозвіл на демонстрацію екрана, передавання файлів, показ презентації тощо);

- робота з віртуальною дошкою (використання віртуальних інструментів, а саме - маркерів, олівців, гумки тощо);

- організація загального та/або приватного чату (текстовий зв'язок учасників вебінару).

Робота в BigBlueButton відбувається через браузер і не потребує від слухачів встановлення клієнтського забезпечення, що значно полегшує організацію вебінару (для входу у віртуальний клас користувачам достатньо перейти за посиланням). Учасники вебінару на платформі BigBlueButton можуть бути віднесені до таких категорій - ведучий, модератор, слухач. Кожна категорія користувачів може отримати доступ до тих чи інших функцій платформи і виконувати певні дії. Ведучий - викладач, який проводить заняття, показує презентації, обговорює різні питання із слухачами, може включити трансляцію свого робочого столу або вікна програми, використовувати інструменти віртуальної дошки.

Ведучих може бути кілька, зазвичай для зручності, ведучих двоє: один (лектор) пояснює навчальний матеріал, інший (асистент) йому допомагає. Модератор - це особа, яка має доступ до базових налаштувань вебінару i може призначати ведучих, редагувати чат, здійснювати налаштування віртуальної кімнати, тобто проводити різні роботи, що стосуються технічної сторони. Модератором може бути другий ведучий, який допомагає лектору проводити заняття. Слухач - це учасник, який може слухати викладача, писати текстові повідомлення в чаті, завантажувати навчальні матеріали, підготовлені викладачем. Слухач також може виконувати роль ведучого, якщо в цьому $є$ потреба. Наприклад, якщо учасник бажає висловитись із деякого питання у процесі проведення вебінару іншим ведучим, тоді модератор призначає його ведучим. 
Для ефективної роботи BigBlueButton доцільно використовувати окремий сервер під управлінням операційної системи Linux. Платформа BigBlueButton може бути встановлена як 3 вихідного коду, так і з пакетів Linux Ubuntu. Система BigBlueButton може бути завантажена як образ для віртуальної машини, який виконується за програми VMware Player на комп'ютерах як під управлінням OC Windows, так і під Unix, також можливий запуск і в програмі VMWare Fusion в OC MacOS X. Крім того, BigBlueButton може бути інтегрований в такі популярні системи управління вмістом, як Wordpress, Moodle, Joomla!, Drupal тощо. Інтеграція відбувається так само, як і встановлення будь-якого іншого функціонального елементу (плагіну) в системі управління вмістом. Повноцінна робота вебінару буде забезпечена, якщо буде встановлено плагіни для проведення відеоконференції та для iї запису. Зазначимо, що для ЗВО, де немає потужних обчислювальних ресурсів та повноцінного сервера, альтернативою може бути хмаро-орієнтоване середовище, наприклад оренда хостингу віртуальних серверів Amazon EC2 [3].

Незважаючи на те, що процес проведення вебінару доволі простий, все залежить від рівня проведення вебінару. Якщо технічна складова організації вебінару повністю залежить від компетентності адміністратора мережі, то методична - від викладача, який планує провести заняття. Для досягнення високого рівня організації вебінару викладачеві потрібно затратити багато часу і сил на організаційні моменти проведення такого заняття: спланувати свої дії та передбачити дії слухачів, підготувати можливі запитання та відповіді на них, продумати форму поточного контролю та оцінити його об’єктивність тощо. Нині існують окремі організації, які займаються виключно організацією вебінарів і допомогою у їх проведенні. Проте маючи відповідний інструментарій та педагогічну майстерність, викладач може й сам організувати таке заняття.

Слід відзначити, що на відміну від традиційного заняття в аудиторії, вебінар потребує проведення спеціальних організаційних заходів.

Початкова підготовка до заняття включає визначення теми, плану роботи, розроблення змісту та мультимедійних ресурсів. Проте, на відміну від аудиторного заняття, підготовка до вебінару потребує більш докладного аналізу веб-інструментарію платформи проведення вебінарів та врахування психолого-педагогічних особливостей цієї форми організації навчання.

Для ефективної взаємодії викладача зі студентами складається план подання матеріалу та його опрацювання учасниками. Наприклад, якщо навчальний матеріал подається у вигляді презентації, то до кожного слайду презентації потрібно продумати коментар. Теоретичний матеріал необхідно подавати дозовано (6-10 хв.), після яких здійснювати інтерактивну взаємодію зі студентами, наприклад ставити запитання, проводити опитування, обговорення (до 5 хв.). Важливо заздалегідь визначити місце інтерактивної взаємодії зі учасниками в межах вебінару і підготувати запитання. Як правило, місце для запитань залишають або в кінці, або після кожного змістового блоку теми.

Під час складання плану роботи вебінару потрібно визначитись із датою проведення заняття, часом, тривалістю вебінару, кількістю студентів, які планують слухати вебінар. Важливим заходом $\epsilon$ розроблення матеріалів для подальшої самостійної роботи. Це дасть змогу закріпити знання, отримані на занятті, а викладачеві - перевірити, наскільки уважними були студенти під час вебінару.

Сповіщення студентів про проведення вебінару доцільно скласти у вигляді інформаційного листа-запрошення. У таких сповіщеннях, окрім дати і часу проведення вебінару, доцільно також надсилати матеріали, з якими студентам потрібно ознайомитися перед початком вебінару. Це мають бути матеріали, що стосуються теми вебінару, мети його проведення, завдань тощо. Основним спрямуванням матеріалів має бути актуалізація опорних знань суб'єктів навчання, але в жодному разі не коротке, або розширене подання змісту навчання. Крім того, учасникам важливо надати методичні рекомендації для участі у вебінарі, наприклад, це можуть бути відомості про технічні засоби, які потрібно мати для роботи у вебінарі.

Для попередження будь-яких технічних несправностей завжди доцільно здійснювати попереднє тренування доповідача, тестування технічного обладнання, програмної платформи та іiї функціоналу (роботу мікрофону, веб-камери, переключення слайдів, запис вебінару тощо). Ця діяльність виконується у співробітництві з адміністратором, який відповідає за технічну сторону роботи.

Отже, підготовка до вебінару займає значно більше часу, ніж до звичайного заняття, проте підготувавшись один раз, наступного разу ця діяльність займе значно менше часу. Практика переконує, що процес підготовки до вебінару можна звести до мінімуму, якщо в організатора $\epsilon$ відповідний досвід і знання.

Таким чином, дотримання методичної, технічної та організаційної складові проведення вебінарів $\epsilon$ надзвичайно важливим для досягнення позитивного результату у підготовці фахівців. Для забезпечення другої складової підготовки IT-фахівця (рис. 1) - змістової, доцільно залучити їх до визначення технічної складової організації вебінарів - аналіз платформ проведення вебінарів, 
вивчення апаратного забезпечення, визначення мінімального, але достатнього набору технічних засобів для проведення вебінарів як для слухачів, так і для ведучого, тощо.

Висновки. Використання технології вебінарів значно розширює можливості організації освітнього процесу, сприяє формуванню у майбутніх IT-фахівців системи технічних понять, знань та умінь в галузі проведення онлайнових занять і таким чином удосконалити практико-технічну підготовку студентів. Практика засвідчує, що практично всі види аудиторних занять у традиційній освіті можуть бути реалізовані засобами вебінарів. Проте ряд проблем такої технології як форми організації навчання не дають підстави для повної заміни традиційного аудиторного навчання. Ї̈ї використання дає змогу значно покращити та вдосконалити освітній процес, перевести на інший рівень процес осмислення навчального матеріалу, урізноманітнити форми організації навчальної діяльності.

\title{
Список використаних джерел
}

[1] Морзе Н.В., Ігнатенко О.В. Методичні особливості вебінарів, як інноваційної технології навчання. Інформачійні технології в освіті. 2010. Вип. 5. С. 31-39.

[2] Освіта в Європі у 2020-2030 роках. Прогноз. URL: http://www/pontydysgu.org/2010/01/crowdsourcing-the-turopeanforesight-study-your=chance-to-be-an-expert.

[3] Словінська О. Д. Вебінар як різновид електронної веб-конференції та його місце у мережевому колаборативному навчальному процесі. Інформаиійні технології в освіті. 2013. Вип. 17. С. 173 177.

[4] Ткачук Г.В. Особливості організації та проведення вебінарів засобами платформи BigBlueButton. Комп 'ютер в школі та сім'ї. 2016. №2 (130). С. 43-46.

[5] BigBlueButton. URL: http://bigbluebutton.org.

[6] Etutorium. URL: https://etutorium.com.ua.

[7] GoToWebinar. URL: http://www.gotomeeting.com.

[8] The Cambridge English Dictionary. URL: https://dictionary.cambridge.org.

[9] Webex. URL: https://www.webex.com/.

[10] Webinar.ua. URL: http://webinar.ua.

\section{References}

[1] Morze N.V., Ihnatenko O.V. (2010) Methodical features of webinars as innovative teaching technology. Information technology in education. 2010. Vol.5. Pp.31-39. (in Ukrainian).

[2] Education in Europe in 2020-2030 years. Forecast. URL: http://www/pontydysgu.org/2010/01/crowdsourcing-the-turopeanforesight-study-your=chance-to-be-an-expert. (in Ukrainian).

[3] Slovinska O.D. (2013) Webinar as a kind of e-web conference and its place in the online collaborative learning process. Information technology in education. 2013. Vol. 17. Pp. 173-177. (in Ukrainian).

[4] Tkachuk H.V. (2016) Features of organizing and conducting webinars by means of the platform BigBlueButton. Computer in school and family. 2 (130). Pp. 43-46. (in Ukrainian).

[5] BigBlueButton. URL: http://bigbluebutton.org.

[6] Etutorium. URL: https://etutorium.com.ua.

[7] GoToWebinar. URL: http://www.gotomeeting.com.

[8] The Cambridge English Dictionary. URL: https://dictionary.cambridge.org.

[9] Webex. URL: https://www.webex.com.

[10] Webinar.ua. URL: http://webinar.ua.

\section{P.M. Malezhyk, H.V. Tkachuk \\ ORGANIZATION OF PRACTICAL AND TECHNICAL TRAINING OF FUTURE IT SPECIALISTS WITH THE HELP OF WEBINARS}

\begin{abstract}
The analysis of modern scientific and educational-methodological literature has led to the conclusion that today there is an insufficient number of professional-oriented educational literature on the use of webinar technology in the educational process. This article presents a comprehensive study that examines software issues, organizational and methodological requirements for conducting webinars, platform selection. Prerequisites have been considered, the process of creation has been described, functional possibilities and results of the system of training of technical disciplines of future specialists in information technologies have been analyzed. A large number, of well-known webinar support platforms include the BigBlueButton platform, which is free and freely distributed open-source software.

A number, of organizational and methodological measures for a successful webinar have been described and recommended. It has been noted that adherence to the methodological, technical, and organizational component of conducting webinars is extremely important for achieving a positive result in the training of
\end{abstract}


specialists. It has been shown that the use of webinars technology greatly enhances the organization of the educational process, contributes to the formation of a system of technical concepts, knowledge, and skills in the field of online classes for future IT professionals, and thus provides an opportunity to improve the practical and technical training of students.

Despite all the inconveniences, virtually all types of classroom instruction in traditional education can be implemented through webinars. However, a number, of problems with such technology as a form of training organization do not warrant the complete replacement of traditional classroom training. Its use makes it possible to significantly improve and improve the educational process, to take to another level the process of comprehension of educational material, to diversify the forms of organization of educational activities.

Keywords: future IT specialists, educational process, technical disciplines, practical training, organization of webinar.

\title{
DOI 10.31392/NPU-nc.series 2.2020.22(29).08 \\ УДК 378.011.3-051:373.2]:004
}

\author{
Наталія Петрівна Франчук \\ Національний педагогічний університет імені М.П. Драгоманова, \\ кандидат педагогічних наук, доцент \\ ORCID ID: 0000-0002-0213-143X \\ n.p.franchuk@npu.edu.ua
}

\section{ДЕЯКІ АСПЕКТИ ВИКОРИСТАННЯ КОМП'ЮТЕРНИХ ТЕХНОЛОГІЙ ПІД ЧАС НАВЧАННЯ МАЙБУТНІХ ВИХОВАТЕЛІВ ЗАКЛАДІВ ДОШКІЛЬНОЇ ОСВІТИ}

Анотація. Використання інформаційно-комунікаційних технологій у навчально-виховному процесі в закладах дошкільної освіти - це одна з актуальних проблем дошкільної педагогіки. Діти 3 великим задоволенням виконують завдання та активно працюють на заняттях 3 використанням комп'ютерних засобів. Підвищують увагу дітей через різноманітні мультиплікації, звук, яскраву кольорову гаму та динаміка рисунків. Саме через це майбутній вихователь повинен вміти добирати, використовувати, гармонійно поєднувати та створювати актуальний зміст для дітей дошкільного віку. Основи комп'ютерної грамотності та знайомство 3 навколишнім світом за допомогою комп'ютера входить до циклу природничо-наукової підготовки фахівців. Студенти, які навчаються за галуззю знань 01 Освіта/Педагогіка спеціальність 012 Дошкільна освіта освітньо-кваліфікаційного ступеня «Бакалавр», повинні бути готовими до використання комп'ютерних технологій в роботі 3 дітьми. Предметом навчання дисципліни «Комп’ютерні технології в роботі з дітьми» $є$ процес формування у майбутніх вихователів основних етапів організації навчального процесу 3 використанням комп'ютерних технологій. Метою навчання дисципліни «Комп'ютерні технології в роботі 3 дітьми» є підготовка майбутніх вихователів до використання комп'ютерних технологій в роботі з дітьми. Головний акцент зроблений на особливостях використання технічних характеристик комп'ютера як нового специфічного засобу діяльності дитини та використанні під час роботи 3 дітьми програмних засобів навчального призначення (дидактичні ігри, розвивальні програми, навчально-ігрові комплекси тощо); формування у студентів обізнаності щодо ефективного використання існуючих інформаційних технологій з метою організації навчально-виховного процесу для використання різноманітних навчально-виховних завдань.

В статті описано лабораторні роботи для студентів, які навчаються за галуззю знань 01 Освіта/Педагогіка спеціальність 012 Дошкільна освіта освітньо-кваліфікаційного ступеня «Бакалавр».

Ключові слова: майбутні вихователі, заклад дошкільної освіти, комп'ютерна грамотність, інформаційно-комунікаційні технології.

Дисципліни «Комп'ютерні технології в роботі 3 дітьми» навчають на другому курсі. На опанування дисципліною відводиться 4 кредити ЄКТС (120 годин). Одним із важливих компонентів програми $є$ міждисциплінарне узгодження. Цього курсу навчають студентів з використанням системи управління навчальними курсами MOODLE (https://moodle.npu.edu.ua/course/view.php?id=1178 див. Рис. 1) після того, як вони опанували дисципліни: «Нові інформаційні технології», «Дитяча психологія», «Дошкільна педагогіка» та засвоїли характеристики найважливіших технічних i програмних засобів. 